\title{
Analisis Pengaruh Iklan Dan Harga Terhadap Keputusan Pembelian Minuman Teh Pucuk Harum Pada Konsumen De Nala Foodcourt
}

\author{
Ratna Dwi Jayanti ${ }^{1}$, Mochammad Zalaluddin Zuhri ${ }^{2}$ \\ STIE PGRI Dewantara Jombang \\ ratna.stiedw@gmail.com ${ }^{2}$, zuhri.ahmad@gmail.com ${ }^{2}$
}

Diserahkan: 15 Januari 2017, Diterima: 20 Pebruari 2017

\begin{abstract}
This research was conducted based on the phenomenon that occurred in the market share of Teh Pucuk Harum (Pucuk Harum Tea), the product which experienced a significant increase from previous years, so it can compete with other tea beverage products in other packaging. This study aims to determine the effect of Advertising and Price on consumer purchasing decisions of Teh Pucuk Harum. This research was conducted on De Nala FoodCourt Jombang and involved 74 consumers as samples. The research method was quantitative explanation analysis with the aim to know how big influence of independent variable to dependent variable. The method of data collection was by distributing the questionnaire containing the statements that each item contains about the indicator of the variables studied and being tested by multiple regression analysis using SPSS software.

The results of this study revealed that there are simultaneous and partial effects between advertising and price variables on purchasing decisions of shoots of Harum Tea product at De Nala FoodCourt consumer Jombang

Keywords: Advertising, Price, Purchase Decision.
\end{abstract}

\section{abstrak}

Penelitian ini dilakukan berdasarkan adanya fenomena yang terjadi pada pangsa pasar produk Teh Pucuk Harum yang mengalami peningkatan yang cukup signifikan dari tahuntahun sebelumnya, sehingga dapat menyaingi produk minuman teh dalam kemasan lainnya. Penelitian ini bertujuan untuk mengetahui pengaruh Iklan dan Harga terhadap keputusan pembelian konsumen Teh Pucuk Harum. Penelitian ini dilakukan pada konsumen De Nala FoodCourt Jombang dengan jumlah sampel 74 responden. Metode penelitian analisis kuantitatif eksplanasi dengan tujuan untuk mengetahui seberapa besar pengaruh variabel bebas tersebut terhadap variabel terikat. Metode pengumpulan data adalah dengan penyebaran kuesioner yang berisi pernyataan-pernyataan yang tiap itemnya berisi mengenai indikator dari variabel-variabel yang diteliti. Setelah itu dilakukan uji dengan analisis regresi berganda yang menggunakan software SPSS.

Hasil penlitian ini mengungkapkan bahwa terdapat pengaruh secara simultan maupun parsial antara variabel iklan dan harga terhadap keputusan pembelian produk Teh Pucuk Harum pada konsumen De Nala FoodCourt Jombang

Kata Kunci : Iklan, Harga, Keputusan Pembelian.

\section{A. PENDAHULUAN}

Di era globalisasi ini teknologi informasi merupakan hal yang sangat dibutuhkan oleh masyarakat. Karena dengan adanya teknologi informasi, segala hal yang ingin diketahui oleh masyarakat dapat diakses kapanpun dan dimanapun. Kebutuhan akan teknologi informasi ini juga didukung dengan adanya perkembangan teknologi yang semakin canggih, mulai dari perkembangan alat produksi, alat transportasi, alat telekomunikasi, dan lain sebagainya. Perkembangan teknologi informasi pada saat ini betul-betul dimanfaatkan oleh pemasar untuk memasarkan produknya agar dikenal oleh konsumen. Berbagai alat yang dapat memberikan informasi digunakan oleh pemasar dalam memasarkan produknya, antara lain melalui media TV, radio, internet, billboard, koran, dan sebagainya. Tentu tujuan dari pemasar melakukan hal tersebut adalah untuk memenangkan persaingan dalam pasar industri. Persaingan antara perusahaan baru dan 
perusahaan yang telah lama berkecimpung dalam industri yang sama sangatlah ketat. Perusahaan lama bertujuan untuk mempertahankan pangsa pasar yang telah dimiliki, disisi lain perusahaan baru ingin mengambil pangsa pasar yang telah dikuasai oleh perusahaan yang lama.

Dengan perkembangan zaman yang semakin cepat, manusia cenderung ingin melakukan segala sesuatu dengan cepat, demikian pula dengan konsumsi makanan dan minuman yang tersedia secara instan, maka muncullah produk baru seperti makanan cepat saji, mie instan, dan teh instan. Makanan dan minuman instan ini sangat digemari oleh masyarakat di seluruh dunia, karena segala aktifitas tidak terganggu dengan proses pembuatannya. Produk teh instan tertua di Indonesia adalah Teh Botol Sosro yang diproduksi oleh PT. Sinar Sosro pada tahun 1974. Teh Botol Sosro bahkan lebih digemari masyarakat Indonesia daripada Coca-Cola. Hal tersebut didukung oleh hasil penelitian majalah $S W A$, hasil tersebut juga masih konsisten dengan penelitian tahun 2011 oleh Youthlab Indonesia, 84\% pemuda Indonesia lebih memilih Teh Botol Sosro dibandingkan Coca-Cola. Kebutuhan masyarakat akan produk teh instan menarik perhatian perusahaan-perusahaan muda, seperti PT. Mayora Indah Tbk atau Mayora Group yang didirikan pada 17 Februari 1977. Perusahaan ini meluncurkan produk teh instan dengan merek Teh Pucuk Harum, yang akhir-akhir ini sering dipromosikan di media cetak, iklan dan billboard.

Teh Pucuk Harum diluncurkan pada tahun 2011, akan tetapi merek ini sukses di pasar dan dapat bersaing dengan merek-merek ternama seperti Sosro, Indofood, Orang Tua, Garuda Food, dan juga Wings Food. Dalam tiga tahun terakhir saja Teh Pucuk mampu bersaing dan mengalahkan merek yang lebih dahulu muncul seperti Ultra Teh Kotak, Teh Gelas, dan Frestea. Prestasi Teh Pucuk Harum paling terlihat di tahun 2016 saat Top Brand Index (TBI) Teh Pucuk Harum melonjak tajam hingga enam kali lipat dari tahun sebelumnya. Jika pada tahun 2015 Teh Pucuk Harum menempati posisi ke-6 dengan TBI 4.1\%, tahun 2016 TBI Teh Pucuk Harum mencapai 24.8\%. Perolehan ini mendudukkan Teh Pucuk Harum di posisi ke-2 dengan gap indeks hanya terpaut $9.0 \%$ dari market leader Teh Botol Sosro.

Tabel 1: Top Brand Index Kategori Teh Siap Minum dalam Kemasan 2016 Fase 1

\begin{tabular}{|c|c|c|}
\hline \multicolumn{3}{|c|}{ TEH DALAM KEMASAN SIAP MINUM } \\
\hline MEREK & TBI & TOP \\
\hline Teh Botol Sosro & $33.8 \%$ & TOP \\
\hline Teh Pucuk Harum & $24.8 \%$ & TOP \\
\hline Teh Gelas & $13.1 \%$ & TOP \\
\hline Ultra Teh Kotak & $8.1 \%$ & \\
\hline Frestea & $7.2 \%$ & \\
\hline
\end{tabular}

Sumber : top brand index 2016 fase 1

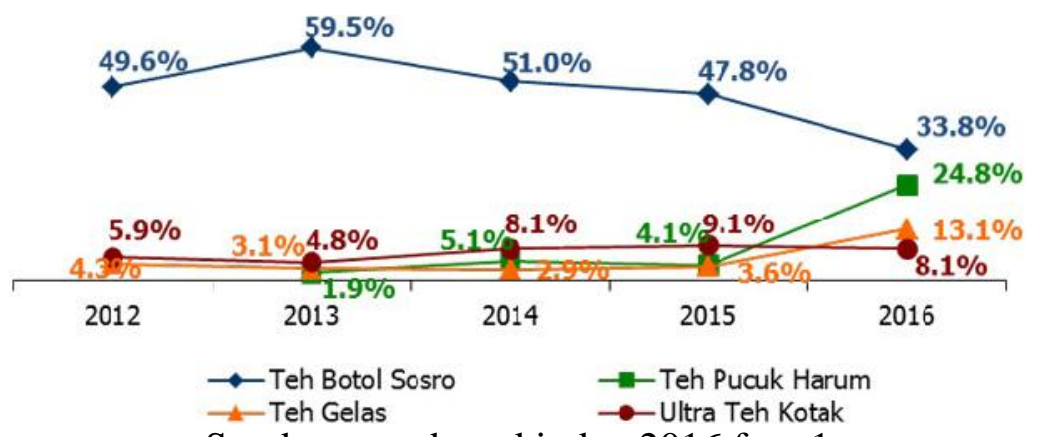

Sumber : top brand index 2016 fase 1 
Dari data tersebut dapat dilihat bahwa Teh Pucuk Harum mempunyai tren yang sangat positif dengan di lihat adanya kenaikan market share yang cukup signifikan. Tentu ini merupakan hal yang sangat menarik karena mengingat produk tersebut adalah produk baru, tetapi dapat bersaing bahkan mengalahkan produk-produk sebelumnya.

Salah satu strategi bersaing yang dirumuskan oleh Michael E. Porter (1980) adalah differentiation. Strategi ini mendorong perusahaan untuk berinovasi menciptakan keunikan tersendiri untuk membangun merek yang kuat. Membuat iklan yang unik dan menarik dilakukan oleh perusahaan serta diperkuat dengan tagline-nya "Rasa teh terbaik ada di pucuknya". Dari iklan ini, Teh Pucuk Harum mengedukasi masyarakat bahwa rasa teh terbaik hanya diperoleh dari pucuk daun. Strategi diferensiasi ini efektif menarik perhatian pendengar atau calon konsumen, terutama bagi pendatang baru, dalam menciptakan brand awareness.

Fungsi iklan tidak hanya untuk mengenalkan produk yang ditawarkan, akan tetapi juga dapat memberikan ajakan atau edukasi untuk memberikan perspeksi bagi konsumen yang akan mengkonsumsi produk tersebut. "Iklan yang baik akan menghasilkan hasil yang memuaskan”, mungkin itulah strategi dari Philip Kotler yang di ambil oleh Teh Pucuk Harum dalam mengenalkan produknya. Iklan selain mempunyai tujuan untuk mengenalkan produk kepada konsumen, tetapi iklan juga bertujuan untuk memberikan ajakan kepada konsumen untuk menggunakan atau membeli produk yang ditawarkan.

Teh Pucuk Harum juga melakukan diferensiasi melalui kemasan, sehingga dianggap sebagai pelopor minuman teh kemasan botol plastik dengan kemasan botol berisi $350 \mathrm{ml}$. Kemasan yang lebih kecil ini membuka kesempatan bagi Mayora untuk menekan harga eceran tertinggi yang ditawarkan ke pasar. Teh Pucuk Harum dijual di pasaran dengan harga eceran tertinggi Rp3.500. Pada akhirnya, kemasan ekonomis ini sangat baik digunakan untuk dapat bersaing untuk target pasar teh siap minum yang konsumennya melakukan pertimbangan harga dalam membeli produk. Harga yang rendah akan menciptakan keinginan konsumen untuk mencoba. Strategi penetapan harga yang tepat akan dapat membuat produk menjadi lebih diminati oleh konsumen, tentunya dengan tidak mengesampingkan kualitas dari produk yang ditawarkan. Strategi penetapan harga ini sangat penting bagi suatu perusahaan yang meluncurkan produk baru. Karena apabila harga terlalu rendah konsumen akan berfikir produk kurang berkualitas, akan tetapi bila harga di patok terlalu tinggi juga akan menyebabkan daya beli masyarakat rendah. Untuk itu perlu strategi yang tepat bagi perusahaan untuk menentukan harga yang sesuai dengan keinginan pasar, tetapi disertai dengan mutu produk yang tetap terjaga.

De Nala Foodcourt adalah satu tempat makan anak-anak muda yang berada di pusat kota Jombang. Food court ini terdiri atas beberapa penjual (court) yang menyediakan beberapa menu makanan yang digemari anak muda. Meskipun di De Nala Food Court juga meneydiakan beberapa penjual minuman dengan racikan sendiri seperti aneka minuman dingin dan milshake, tetapi masih banyak konsumen terutama anakanak muda yang masih memilih Teh Pucuk Harum sebagai minumannya. Hal ini karena rasanya yang sudah familiar, harga yang terjangkau, juga karena kemasannya yang mudah dibawa kemana-mana.

Para anak muda inilah yang dinilai oleh peneliti sebagai konsumen yang sangat sensitif terhadap harga dan switcing cost yang rendah. Karena kelompok konsumen ini termasuk dalam kategori yang sangat mudah terpengaruh dengan harga. Kelompok anak muda akan lebih mempertimbangkan harga produk sebagai konsumsinya. 
Berdasarkan masalah tersebut maka rumusan masalah yang diangkat dalam penelitian ini adalah: apakah iklan dan harga berpengaruh terhadap keputusan pembelian minuman Teh Pucuk Harum baik secara parsial maupun simultan.

Penelitian ini diharapkan dapat memberikan manfaat bagi pihak-pihak yang berkepentingan, terutama bagi perusahaan Teh Pucuk Harum yaitu PT Mayora serta pihak-pihka lain yang ingin melakukan penelitian serupa.

\section{B. TINJAUAN PUSTAKA Pengertian Iklan}

Menurut Shimp (2003:42), "Iklan merupakan suatu investasi ekonomis, dan bagi kebanyakan perusahaan dan organisasi non profit, iklan merupakan sebuah investasi yang dianggap sangat menguntungkan. Periklanan (advertisisng) adalah semua bentuk terbayar atas presentasi nonpribadi dan promosi ide, barang, atau jasa oleh sponsor yang jelas (Kotler \& Keller 2009:202).

Menurut Aaker yang dikutip Tjiptono (2001:103) menyatakan bahwa iklan memegang peranan penting dalam pemasaran karena iklan akan menyampaikan beberapa pesan diantaranya adalah brand awareness, strong brand association, perceived quality, dan brand loyality.

Menurut Frank Jefkins (1997:227), dalam suatu iklan terdapat beberapa atribut iklan yang merupakan isi dari periklanan, yaitu :

1. Pesan Iklan (message), yaitu penjumlahan dari tanda atau sinyal yang berusaha mengungkapkan satu atau lebih gagasan.

2. Naskah Iklan (copywrite). Pesan yang paling persuasive dan kuat. Tujuh unsur naskah iklan adalah headline, sub judul, teks, harga, nama, alamat dan signature slogan.

3. Desain Iklan, yaitu rancangan layout iklan atau gambar iklan yang menyertakan naskah iklan, kata, kalimat headline, sub-heading, dan teks

4. Model Iklan, yaitu Seorang/sekelompok orang atau sesuatu yang dijadikan sebagai daya tarik atau pendukung bahkan dijadikan maskot bagi produk iklan yang diiklankan.

5. Warna dan Musik. Warna iklan dan musik merupakan atribut yang akan membuat iklan itu semakin menarik.

\section{Definisi Harga}

Menurut Basu Swastha \& Irawan (2005:241) harga merupakan jumlah uang (ditambah beberapa produk kalau mungkin) yang dibutuhkan untuk mendapatkan sejumlah kombinasi dari produk dan pelayanannya. Harga menurut Kotler dan Armstrong (2001:439) adalah sejumlah uang yang dibebankan atas suatu produk atau jasa, atau jumlah dari nilai yang ditukar konsumen atas manfaat-manfaat karena memiliki atau menggunakan produk atau jasa tersebut.

\section{Penetapan Harga}

Kotler \& Keller (2009:76) menyatakan langkah-langkah dalam menentukan kebijakan penetapan harga perusahaan yaitu; Memilih Tujuan Penetapan Harga, Menentukan Permintaan, Memperkirakan Biaya, Harga dan Penawaran Pesaing, Memilih Metode Penetapan Harga, dan Memilih Harga Akhir.

Ada beberapa indikator dari harga. Pertama, Harga terjangkau. Harga terjangkau artinya harga produk tersebut tidak terlalu mahal sehingga konsumen dapat membeli produk tersebut. Kedua, Harga bersaing. Harga bersaing artinya harga produk tersebut dapat bersaing dengan produk lain yang sejenis. Ketiga Harga memiliki kesesuaian 
dengan kualitas. Harga memiliki kesesuaian dengan kualitas artinya dengan harga yang ditawarkan produk tersebut juga mempunyai kualitas yang baik.

\section{Tujuan Penetapan Harga}

Perusahaan akan menentukan mulai dari produk, segmentasi, biaya-biaya promosi atau iklan, dan biaya-biaya lain sebagai pertimbangan dalam memutuskan harga produk. Menurut Tjiptono (2005:35) ada 4 hal yang menjadi tujuan penetapan harga, yaitu; Tujuan berorientasi pada laba ,tujuan berorientasi pada volume, tujuan berorientasi pada citra, tujuan stabilisasi harga, dan tujuan-tujuan lainnya.

\section{Keputusan Pembelian}

Konsumen ketika akan melakukan pembelian terhadap suatu produk akan mempertimbangkan produk tersebut apakah sesuai dengan apa yang mereka harapkan. Pertimbangan yang dilakukan konsumen ini juga tidak terlepas dari banyaknya pilihan produk-produk yang ditawarkan oleh produsen. Untuk itu produsen akan selalu memberikan produk-produk yang diharapkan bisa memenuhi kebutuhan dan keinginan konsumen.

Perilaku konsumen adalah studi tentang bagaimana individu, kelompok, dan organisasi memilih, membeli, menggunakan, dan bagaimana barang, jasa, ide, atau pengalaman untuk memuaskan kebutuhan dan keinginan mereka (Kotler \& Keller, 2009:166). Perilaku pembelian konsumen dipengaruhi oleh faktor budaya, sosial, pribadi dan psikologis. Produsen akan ketika akan meluncurkan produk baru, atau sekedar akan melakukan inovasi terhadap produknya akan selalu mempertimbangkan faktor-faktor tersebut.

Menurut Kotler \& Keller (2009:184) tahap-tahap proses keputusan pembelian antara lain; pengenalan masalah, pencarian informasi, evaluasi alternatif, keputusan pembelian, dan perilaku pascapembelian.

Indikator-indikator keputusan pembelian adalah: 1) Kemantapan pada sebuah produk, 2) Kebiasaan dalam membeli produk, 3) Memberikan rekomendasi kepada orang lain. Dan 4) Melakukan pembelian ulang.

\section{Hubungan Iklan dengan Keputusan Pembelian}

Bentuk iklan yang menarik akan membuat rasa ingin membeli konsumen menjadi tinggi. Penyampaian iklan dengan semenarik mungkin dapat mempengaruhi konsumen untuk selalu mengingat produk tersebut, sehingga dampaknya pada pilihan konsumen ketika memilih produk.

Menurut Kotler (2003), iklan bertujuan untuk membangun kesadaran akan pentingnya suatu produk atau jasa, membantu meyakinkan pelanggan dalam membeli dan membedakan suatu produk/jasa tersebut dengan produk/jasa yang lain. Iklan visual dapat menancapkan kesan yang lebih dalam, sehingga para konsumen begitu melihat produk akan segera teringat akan suatu merek tersebut (Jefkins, 1997). Periklanan harus mampu membujuk konsumen agar tertarik terhadap suatu produk yang diiklankan. Periklanan yang dirancang dengan baik akan mengarahkan konsumen membeli produk yang ditawarkan produsen, sehingga konsumen yakin bahwa produk tersebut dapat memenuhi kebutuhan dan keinginan konsumen. Melalui iklan produsen harus mampu mempengaruhi pemilihan dan keputusan pembelian konsumen (Jefkins, 1997:15).

Model AIDA (Attention, Interest, Desire, Action) yang dikemukakan Kotler \& Keller (2012:502) menjelaskan bagaimana proses komunikasi dapat mempengaruhi konsumen salah satunya melalui iklan. Perhatian (Attention) konsumen perlu ditingkatkan melalui iklan agar tertarik untuk mencoba suatu produk baru yang dikeluarkan perusahaan sebagai pemenuh kebutuhan dan keinginan masyarakat. 
Kemudian dilakukan penyesuaian iklan terhadap target konsumen dan pemilihan media yang sesuai, iklan yang disampaikan harus menarik sehingga konsumen tertarik (Interest) pada produk yang ditawarkan. Dengan menggunakan media dalam periklanan akan meningkatkan keinginan (Desire) konsumen untuk mencari tahu tentang produk yang ditawarkan. Setelah mendapat informasi mengenai produk tersebut melalui iklan maka konsumen diharapkan melakukan tindakan (Action) pembelian terhadap produk tersebut.

Penelitian yang dilakukan Dimas Aditya Pradana (2012) memberikan hasil penelitian variabel iklan berpengaruh positif terhadap keputusan pembelian samrtphone Sony Xperia. Dan penelitian lain yang dilakukan Aji Normawan Rosyid, Handoyo Djoko W, dan Widayanto (2013) menunjukkan hasil bahwa Iklan berpengaruh positif terhadap keputusan pembelian sepeda motor Honda Revo pada konsumen Astra Motor Kebumen. Berdasarkan pernyataan tersebut maka diajukan hipotesis sebagai berikut :

$\mathrm{H}_{1}=$ Terdapat pengaruh iklan terhadap keputusan pembelian minuman Teh Pucuk Harum.

\section{Hubungan Harga dengan Keputusan Pembelian}

Peranan harga dalam keputusan pembelian konsumen yaitu mengenai ekspektasi manfaat atau utilitas yang akan diterima oleh konsumen berdasarkan sejumlah harga yang dibayar konsumen untuk mendapatkan produk atau jasa. Informasi mengenai harga merupakan pertimbangan konsumen. Dalam hal ini konsumen akan membuat penilaian mengenai kesesuaian harga dan manfaat atas suatu produk atau jasa.

Harga memiliki dua peranan utama dalam proses pengambilan keputusan para pembeli, yaitu peranan alokasi dan peranan informasi (Tjiptono, 2008) :

1. Peranan alokasi dari harga, yaitu fungsi harga dalam membantu para pembeli untuk memutuskan cara memperoleh manfaat atau utilitas tertinggi yang diharapkan berdasarkan daya belinya. Dengan demikian, adanya harga dapat membantu para pembeli untuk memutuskan cara mengalokasikan daya belinya pada berbagai jenis barang dan jasa. Pembeli membandingkan harga dari berbagai alternatif yang tersedia, kemudian memutuskan alokasi dana yang dikehendaki.

2. Peranan informasi dari harga, yaitu fungsi harga dalam 'mendidik' konsumen mengenai faktor-faktor produk, seperti kualitas. Hal ini terutama bermanfaat dalam situasi dimana pembeli mengalami kesulitan untuk menilai faktor produk atau manfaatnya secara objektif. Persepsi yang sering berlaku adalah bahwa harga yang mahal mencerminkan kualitas yang tinggi.

Harga merupakan salah satu faktor penentu pembeli dalam menentukan suatu keputusan pembelian terhadap suatu produk maupun jasa. Apalagi apabila produk atau jasa yang akan dibeli tersebut merupakan kebutuhan sehari-hari seperti makanan, minuman dan kebutuhan pokok lainnya, pembeli akan sangat memperhatikan harganya. Pengusaha perlu untuk memperhatikan hal ini, karena dalam persaingan usaha, harga yang ditawarkan oleh pesaing bisa lebih rendah dengan kualitas yang sama atau bahkan dengan kualitas yang lebih baik. Sehingga dalam penentuan harga produk atau jasa yang dijual, baik perusahaan besar maupun usaha kecil sekalipun harus memperhatikan pembelinya dan para pesaingnya.

Penelitian yang dilakukan Aji Normawan Rosyid, Handoyo Djoko W, dan Widayanto (2013) menunjukkan bahwa harga berpengaruh positif terhadap keputusan pembelian sepeda motor Honda Revo pada konsumen Astra Motor Kebumen. Berdasarkan pernyataan tersebut maka diajukan hipotesis sebagai berikut : 
$\mathrm{H} 2$ = Terdapat pengaruh harga terhadap keputusan pembelian minuman Teh Pucuk Harum.

Hubungan Iklan dan Harga secara Simultan dengan Keputusan Pembelian

Iklan dan harga mempunyai pengaruh yang cukup kuat dalam keputusan pembelian suatu produk. Karena di dalam iklan biasanya juga akan dimunculkan informasi mengenai harga produk selain juga keunggulan atau spesifikasi produk tersebut. Iklan yang menarik dapat memberikan persepsi dan penilaian produk yang positif bagi konsumen berikut dengan harga yang terjangkau akan sangat berdampak bagi keputusan pembelian konsumen. Penelitian yang dilakukan Dimas Aditya Pradana (2012) berdasarkan hasil regresi linier berganda dengan menggunakan uji F (simultan) menunjukkan bahwa pengaruh iklan, persepsi harga, citra merek dan kepercayaan merek berpengaruh secara simultan terhadap keputusan pembelian produk Android Smartphone Sony Xperia.

Berdasarkan pernyataan tersebut maka diajukan hipotesis sebagai berikut :

H3 = Terdapat pengaruh iklan dan harga secara simultan terhadap keputusan pembelian minuman Teh Pucuk Harum

\section{METODE PENELITIAN}

\section{Rancangan Penelitian}

Penelitian ini dilakukan untuk mengukur pengaruh antara variabel bebas (iklan dan harga) terhadap variabel terikat (keputusan pembelian). Penelitian ini merupakan jenis penelitian kuantitatif eksplanasi dengan tujuan untuk mengetahui seberapa besar pengaruh variabel bebas tersebut terhadap variabel terikat. Metode penelitian kuantitatif merupakan metode penelitian yang menggunakan populasi dan sampel tertentu, pengumpulan data menggunakan instrumen penelitian, analisis data bersifat kuantitatif/statistik dengan tujuan menguji hipotesis yang telah ditentukan (Sugiyono, 2012:7). Penelitian dilakukan pada produk minuman teh siap minum merek Teh Pucuk Harum dengan alasan karena saat ini pangsa pasar Teh Pucuk Harum tinggi dengan melibatkan konsumen De Nala Food Court sebagai subjeknya, sehingga jumlah sampel yang digunakan adalah sebanyak 74 responden. Metode pengumpulan data adalah dengan penyebaran kuesioner yang berisi pernyataan-pernyataan yang tiap itemnya berisi mengenai indikator dari variabel-variabel yang diteliti. Setiap item diberikan penilaian dari pernyataan tersebut yaitu; sangat tidak setuju, tidak setuju, netral, setuju, dan sangat setuju. Skala atau skor penilaian tiap item tersebut menggunakan skala Linkert 1-5. Setelah kuesioner disebar kemudian akan diambil kembali untuk kemudian data diolah dan di uji dengan beberapa teknik analisis data yang menggunakan software SPSS.

\section{Definisi Operasional dan Pengukuran Variabel}

Tabel 1: Definisi Operasional

\begin{tabular}{|c|c|c|}
\hline Variabel & Definisi Operasional & Indikator \\
\hline $\begin{array}{c}\text { Iklan } \\
\text { (X1) }\end{array}$ & $\begin{array}{l}\text { Iklan merupakan suatu pesan mengenai } \\
\text { produk yang di tawarkan untuk disampaikan } \\
\text { oleh pemasar pada konsumen lewat suatu } \\
\text { media, yang bertujuan untuk mempengaruhi } \\
\text { konsumen dalam membeli. }\end{array}$ & $\begin{array}{l}\text { 1. Pesan Iklan } \\
\text { 2. Naskah Iklan (pesan persuasive) } \\
\text { 3. } \begin{array}{l}\text { Desain iklan (rancangan/layout } \\
\text { iklan) }\end{array} \\
\text { 4. } \begin{array}{l}\text { Model iklan (seorang yang } \\
\text { dijadikan sebagai maskot iklan) }\end{array} \\
\text { 5. Warna dan Musik (atribut yang } \\
\text { membuat iklan menarik) }\end{array}$ \\
\hline Harga & $\begin{array}{l}\text { Harga merupakan sejumlah uang yang } \\
\text { dibayarkan untuk mendapatkan suatu produk }\end{array}$ & $\begin{array}{l}\text { 1. Harga terjangkau } \\
\text { 2. Harga bersaing }\end{array}$ \\
\hline
\end{tabular}




\begin{tabular}{|c|l|l|l|}
\hline (X2) & $\begin{array}{l}\text { yang diharapkan produk tersebut dapat } \\
\text { memenuhi kebutuhan dan keinginan } \\
\text { konsumen. }\end{array}$ & $\begin{array}{l}\text { Harga memiliki kesesuaian } \\
\text { dengan kualitas }\end{array}$ \\
\hline $\begin{array}{l}\text { Keputusan } \\
\text { Pembelian }\end{array}$ & $\begin{array}{l}\text { Keputusan pembelian adalah keputusan } \\
\text { konsumen dalam membeli suatu produk } \\
\text { yang mana dengan produk tersebut } \\
\text { konsumen dapat terpenuhi kebutuhan dan } \\
\text { keinginan konsumen, sehingga merasa puas } \\
\text { dengan produk tersebut. }\end{array}$ & $\begin{array}{l}\text { Kemantapan pada sebuah produk } \\
\text { 3. }\end{array}$ & $\begin{array}{l}\text { Kebiasaan dalam membeli produk } \\
\text { orang lain }\end{array}$ \\
\hline
\end{tabular}

\section{Jenis, Sumber dan Metode Pengumpulan Data}

Jenis data yang digunakan adalah data primer dan data sekunder. Data primer disini yang dimaksudkan adalah data pendukung utama dalam penelitian ini. Data tersebut adalah data-data hasil dari kuesioner yang diisi oleh responden. Sedangkan data sekunder berisi mengenai data pendukung dari data primer dalam penelitian ini yang dapat menjadi bahan acuan. Data sekunder mengenai profil objek penelitian, top brand index dan data-data lain yang diperoleh peneliti dari beberapa sumber; internet, jurnal penelitian, buku-buku dan sumber-sumber lain.

Metode pengumpulan data adalah dengan penyebaran kuesioner kepada mahasiswa di Outlet De Nala Food Court. Kuesioner tersebut diperhitungkan dengan menggunakan skala Likert dengan pemberian skor 1-5 dari setiap item pertanyaan.

\section{Teknik Analisis Data}

\section{Uji Instrumen}

Penelitian ini menggunakan kuesioner untuk mengumpulkan data primer. Demikian pula untuk data sekunder digunakan teknik dokumenter. Untuk kuesioner yang telah disusun dilakukan uji validitras (kebenaran) dan relibilitas (keterandalan).

Validitas yang digunakan dalam penelitian ini (content validity) menggambarkan kesesuaian sebuah pengukur data dengan apa yang akan diukur (Ferdinand, 2006).

Uji validitas dilakukan dengan dua sistem yaitu validitas isi (content validity) dan validitas konstruksi (construct validity). Kedua validitas tersebut dapat diuji melalui menghitung koefisien korelasi antara skor item dengan skor totalnya dengan menggunakan tarif signifikan (alpa) 5\%. Dalam uji t yaitu membandingkan antara pvalue yang dihasilkan dari analisis dengan alpha 5\%. Dan apabila dari hasil perbandingan tersebut p-value lebih besar dari alpha 5\%, maka variabel-variabel yang diteliti dapat dikatakan valid dan sebaliknya.

Reliabilitas adalah alat untuk mengukur suatu kuesioner yang merupakan alat pengukuran konstruk atau variabel. Suatu kuesioner dikatakan reliabel atau handal jika jawaban seseorang, terhadap pertanyaan adalah konsisten atau stabil dari waktu ke waktu (Ghozali, 2006).

Uji reliabilitas dapat dilakukan secara bersama-sama terhadap seluruh butir pertanyaan untuk lebih dari satu variabel, reliabilitas suatu variabel dikatakan baik jika memiliki nilai Cronbach's Alpha > dari 0,60.

Dari hasil uji dengan menggunakan program SPSS atas data primer yang sudah masuk diperoleh nilai Aplha jauh diatas 0,60, jadi dapat disimpulkan bahwa reliabilitas dari seluruh butir pertanyaan pada variabel iklan (X1), harga (X2), dan keputusan pembelian (Y) seluruhnya adalah reliabel. 


\section{Uji Asumsi Klasik}

Untuk uji asumsi klasik menggunakan: 1) Uji Normalitas Data, 2) Uji Multikolinearitas, 3) Uji Heterokedastisitas.

Uji normalitas data bertujuan untuk menguji apakah dalam model regresi, variabel independen dan variabel dependennya memiliki distribusi normal atau tidak. Jika terdapat normalitas, maka residual akan terdistribusi secara normal dan independen (Ghozali, 2006: 27).

Uji Multikolinearitas ditujukan untuk menguji apakah didalam model regresi terdapat korelasi antara variabel bebas (independen). Dalam model regresi yang baik seharusnya tidak terjadi korelasi diantara variabel bebas (Ghozali, 2006: 91).

Uji heteroskedastisitas ditujukan untuk mengidentifikasi ada atau tidaknya ketidaksamaan varian dari residual satu pengamatan ke pengamatan lain di dalam suatu model regresi.

\section{Analisis Regresi Berganda}

Persamaan regresi dalam penelitian ini digunakan sebagai penilaian seberapa besar pengaruh variabel independen (bebas) yaitu Iklan $\left(\mathrm{X}_{1}\right)$ dan Harga $\left(\mathrm{X}_{2}\right)$, terhadap variabel dependen (terikat) yaitu Keputusan Pembelian (Y).

Rumus matematis dari regresi berganda yang digunakan dalam penelitian ini adalah:

$\mathbf{Y}=\mathbf{a}+\mathbf{b}_{1} \mathbf{X}_{1}+\mathbf{b}_{2} \mathbf{X}_{2}+e$

Keterangan :

$\mathbf{Y}=$ Keputusan Pembelian

$\mathbf{a}=$ konstanta

$\mathbf{b}_{\mathbf{1}}=$ Koefisien regresi antara Iklan dengan keputusan pembelian

$\mathbf{b}_{\mathbf{2}}=$ Koefisien regresi antara Harga dengan keputusan pembelian

$\mathbf{X}_{\mathbf{1}}=$ Variabel Iklan

$\mathbf{X}_{\mathbf{2}}=$ Variabel Harga

$\boldsymbol{e}=$ Standard Error

\section{Uji Goodness of Fit}

Untuk uji Goodness of Fit, digunakan Uji T (Uji Parsial), Uji F (Uji Simultan) dan Uji Koefisien Determinasi (R square)

Uji T menunjukkan seberapa jauh pengaruh satu variabel penjelas (independen) secara individual dalam menerangkan variasi variabel dependen.

Uji $\mathrm{F}$ menunjukkan apakah semua variabel independen yang dimasukkan dalam model memiliki pengaruh secara bersama-sama terhadap variabel dependen (Ghozali, 2006: 84).

Uji koefisien determinasi $\left(\mathrm{R}^{2}\right)$ mengukur seberapa jauh kemampuan model dalam menerangkan variasi variabel dependen.

\section{HASIL PENELITIAN DAN PEMBAHASAN}

Untuk mengetahui iklan, harga, atribut harga terhadap pemindahan merek digunakan analisa Model Analysis Regression sederhana dengan program SPSS sebagai berikut :

Tabel 1: Koefisiensi Model Analysis Regression

\begin{tabular}{|c|c|c|c|c|c|c|}
\hline \multirow[b]{2}{*}{ Model } & & \multicolumn{2}{|c|}{$\begin{array}{c}\text { Unstandardized } \\
\text { Coefficients }\end{array}$} & \multirow{2}{*}{$\begin{array}{c}\begin{array}{c}\text { Standardized } \\
\text { Coefficients }\end{array} \\
\text { Beta }\end{array}$} & \multirow[b]{2}{*}{$t$} & \multirow[b]{2}{*}{ Sig. } \\
\hline & & $\mathrm{B}$ & Std. Error & & & \\
\hline & (Constant) & 1.118 & .389 & & 2.870 & .005 \\
\hline & iklan & .257 & .113 & .244 & 2.267 & .026 \\
\hline & harga & .357 & .104 & .372 & 3.446 & .001 \\
\hline
\end{tabular}


Dari tabel tersebut maka didapat persamaan regresi berganda sebagai berikut :

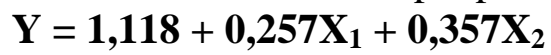

Ketika tidak ada penambahan dalam program periklanan agar periklanan lebih efektif, dan juga tidak ada program penawaran harga khusus bagi konsumen agar dapat menarik konsumen, maka keputusan pembelian akan tetap tidak ada peningkatan.

Nilai koefisien variabel iklan bernilai positif, artinya terjadi pengaruh positif/ searah antara iklan dengan keputusan pembelian teh pucuk harum. Jika perusahaan menambahkan program periklanan agar iklan yang disampaikan lebih efektif, yang dilakukan oleh perusahaan dalam usahanya agar dapat mempengaruhi konsumen, maka keputusan pembelian konsumen akan meningkat.

Nilai koefisien variabel harga bernilai positif, artinya terjadi pengaruh positif/ searah antara harga dengan keputusan pembelian teh pucuk harum. Jika perusahaan menambahkan program penawaran harga khusus dengan diikuti inovasi produk yang tetap dapat memberikan kualitas produk yang baik, maka keputusan pembelian konsumen akan meningkat.

\section{Uji Hipotesis}

Tabel 2: Hasil Uji t Hitung

Coefficients $^{\text {a }}$

\begin{tabular}{|c|c|c|c|c|c|c|}
\hline \multirow{2}{*}{\multicolumn{2}{|c|}{ Model }} & \multicolumn{2}{|c|}{$\begin{array}{l}\text { Unstandardized } \\
\text { Coefficients }\end{array}$} & \multirow{2}{*}{$\begin{array}{c}\text { Standardized } \\
\text { Coefficients }\end{array}$} & \multirow[b]{2}{*}{$t$} & \multirow[b]{2}{*}{ Sig. } \\
\hline & & B & Std. Error & & & \\
\hline \multirow[t]{3}{*}{1} & (Constant) & 1.118 & .389 & & 2.870 & .005 \\
\hline & iklan & .257 & .113 & .244 & 2.267 & .026 \\
\hline & harga & .357 & .104 & .372 & 3.446 & .001 \\
\hline
\end{tabular}

a. Dependent Variable: keputusan pembelian teh pucuk

Sumber: Data Primer diolah, 2016

Dari tabel diatas diketahui bahwa Variabel iklan (X1) memiliki tingkat signifikansi $(<5 \%)$ menghasilkan nilai uji t hitung sebesar 2,267, sedangkan t-tabel $(1,993)$ dengan $\mathrm{df}=\mathrm{n}-\mathrm{k}-1=71$, karena nilai t-hitung lebih besar dari nilai t-tabel $(2,267$ $>1,933$ ) yang berarti $\mathrm{H}_{0}$ ditolak dan $\mathrm{Ha}$ diterima yang menyatakan bahwa ada pengaruh $\mathrm{X}_{1}$ terhadap $\mathrm{Y}$. Dengan demikian iklan berpengaruh signifikan secara parsial terhadap keputusan pembelian teh pucuk harum.

Iklan dapat memberi nilai tambah pada merek dengan mempengaruhi persepsi konsumen atas produk tersebut dan dengan adanya iklan yang dibintangi oleh selebriti akan dapat menambah kepercayaan produk dan meningkatkan keputusan pembelian. Konsumen dalam memutuskan pembeliannya pada produk teh pucuk harum didasarkan pada manfaat yang diinformasikan melalui berbagai kegiatan periklanan yang dilakukan oleh perusahaan, selain itu perusahaan harus lebih meningkatkan program periklanan agar periklanan yang dilakukan lebih efektif. Menurut Fajar Laksana (2008:134) periklanan adalah suatu kegiatan komunikasi yang dapat membentuk kesadaran informasi tertentu, dan selanjutnya memberikan pengaruh untuk melakukan sesuatu yang diharapkan seperti realisasi pembelian, dan membentuk perilaku konsumen yang diharapkan, yaitu pembelian ulang. Karena fungsi iklan selain untuk memberikan informasi tentang produk bagi konsumen, tetapi juga berfungsi untuk mempengaruhi sikap dan minat konsumen dalam memilih produk, serta untuk memotivasi konsumen dalam mengambil tindakan positif yaitu melakukan keputusan pembelian terhadap produk yang ditawarkan. 
Hasil penelitian ini mendukung hasil penelitian terdahulu yang dilakukan oleh Dimas Aditya Pradana (2012) dengan hasil kesimpulan; Pengaruh iklan, persepsi harga, citra merek, dan kepercayaan merek secara simultan, parsial dan dominan mempengaruhi keputusan pembelian. Mendukung pula hasil penelitian yang dilakukan Aji Normawan Rosyid, Handoyo Djoko W, Widayanto (2013) dengan hasil kesimpulan penelitian; Kualitas produk, citra merek, harga, dan iklan berpengaruh positif dan signifikan terhadap keputusan pembelian pada sepeda motor Honda Revo.

Pada pengujian variabel harga, tabel diatas juga menunjukkan bahwa Variabel Harga (X2) memiliki tingkat signifikansi $(<5 \%)$ menghasilkan nilai uji t hitung sebesar 3,446 , sedangkan t-tabel $(1,933)$ dengan $\mathrm{df}=\mathrm{n}-\mathrm{k}-1=71$, karena nilai t-hitung lebih besar dari nilai t-tabel $(3,446>1,933)$ yang berarti $\mathrm{H}_{0}$ ditolak dan Ha diterima yang menyatakan bahwa ada pengaruh $\mathrm{X}_{2}$ terhadap $\mathrm{Y}$. Dengan demikian harga berpengaruh signifikan secara parsial terhadap keputusan pembelian teh pucuk harum.

Menurut Kotler \& Armstrong (2008:345) harga adalah sejumlah nilai yang diberikan oleh pelanggan untuk mendapatkan keuntungan dari memiliki atau menggunakan suatu produk atau jasa. Dan harga merupakan faktor utama dan penting yang mempengaruhi pilihan para konsumen. Kotler (2002) jika perusahaan kurang tepat menetapkan harga, maka hal ini akan berakibat fatal pada keputusan pembelian. Terdapat 3 strategi bersaing dalam memenangkan pasar yang dikemukakan oleh Michael Porter atau yang biasa disebut strategi generik yaitu; 1) Strategi Keunggulan Biaya (Cost Leadership) yang menerapkan strategi perusahaan berusaha mencapai kemampuan biaya produksi dan distribusi yang rendah sehingga dapat memberikan harga produk yang lebih rendah dari pesaing, 2) Strategi Differensiasi yang menerapkan strategi perusahaan lebih memusatkan pada usahanya dalam menciptakan ciri produk yang berbeda dari pesaing, 3) Strategi Fokus yang menerapkan strategi perusahaan memusatkan usahanya untuk melayani sebagian kecil segmen pasar dan tidak melayani pasar secara luas. Apabila dilihat dari strategi generik yang dikemukakan oleh Porter tersebut, maka teh pucuk harum menerapkan strategi Cost Leadership. Hal ini dapat dilihat dari harga teh pucuk harum yang dipatok dengan harga yang rendah dan dapat bersaing dengan produk sejenis, tetapi dengan tidak mengesampingkan kualitas yang baik bagi konsumen. Maka dapat disimpulkan bahwa harga merupakan faktor penting bagi konsumen dalam melakukan keputusan pembelian. Perusahaan diharapkan mampu memberikan program penawaran harga yang menarik bagi konsumen, namun tetap dibarengi dengan kualitas produk yang tidak kalah. Dengan penambahan pada harga tersebut maka akan terjadi peningkatan keputusan pembelian konsumen terhadap teh pucuk harum.

Hasil penelitian ini mendukung hasil penelitian terdahulu yang dilakukan oleh Dimas Aditya Pradana (2012) dengan hasil kesimpulan; Pengaruh iklan, persepsi harga, citra merek, dan kepercayaan merek secara simultan, parsial dan dominan mempengaruhi keputusan pembelian. Mendukung pula hasil penelitian yang dilakukan Aji Normawan Rosyid, Handoyo Djoko W, Widayanto (2013) dengan hasil kesimpulan penelitian; Kualitas produk, citra merek, harga, dan iklan berpengaruh positif dan signifikan terhadap keputusan pembelian pada sepeda motor Honda Revo.

Untuk mengetahui pengaruh variabel bebas terhadap variabel terkait, dapat penulis jelaskan dengan melihat uji simultan yaitu dengan uji $\mathrm{F}$, sebagai berikut : 
Tabel 4: Hasil Uji F

ANOVA

\begin{tabular}{|rl|r|r|r|r|l|}
\hline \multicolumn{1}{|c|}{} & \multicolumn{1}{|c|}{$\begin{array}{c}\text { Sum of } \\
\text { Sodel }\end{array}$} & & df & Mean Square & F & Sig. \\
\hline 1 & Regression & 3.885 & 2 & 1.943 & 7.872 & $.001^{\mathrm{a}}$ \\
& Residual & 17.520 & 71 & .247 & & \\
& Total & 21.405 & 73 & & & \\
\hline
\end{tabular}

a. Predictors: (Constant), harga, iklan

b. Dependent Variable: keputusan pembelian teh pucuk

Sumber : Data Primer diolah, 2016

Dari hasil perhitungan SPSS sebagaimana tersebut di atas, diperoleh nilai $F$ hitung sebesar 7,872, sedangkan $F$ tabel $\left(d f^{2}=\mathrm{n}-\mathrm{k}-1=71\right.$, alpha $\left.=0,05\right)$ adalah sebesar 3,125, artinya diperoleh $F$ hitung $>F$ tabel $(7,872>3,125)$. Yang berarti ada pengaruh secara simultan Iklan dan Harga terhadap Keputusan Pembelian Minuman Teh Pucuk Harum Pada Konsumen De Nala Food Court.

Dari hasil pengujian hipotesis awal didapat hasil bahwa hipotesis yang diajukan diterima yaitu, Variabel iklan dan harga berpengaruh secara simultan terhadap keputusan pembelian teh pucuk harum Pada Konsumen De Nala Food CourtIklan dan harga merupakan faktor yang penting dan sangat berpengaruh terhadap keputusan pembelian konsumen. Karena konsumen ketika akan memutuskan membeli suatu produk, maka hal utama adalah adanya iklan dan harga yang ditawarkan oleh perusahaan. Konsumen akan mendapatkan informasi mengenai suatu produk melalui iklan yang ditampilkan oleh perusahaan, untuk selanjutnya konsumen juga akan melihat harga dengan kesesuaian kualitas produk dan juga termasuk membandingkan harga produk-produk yang sejenis dengan yang ditawarkan perushaan. Maka perlu strategi yang baik dalam menggabungkan kedua faktor iklan dan harga agar dapat meningkatkan keputusan pembelian konsumen. Hasil penelitian ini mendukung hasil penelitian terdahulu yang dilakukan oleh Dimas Aditya Pradana (2012) dengan hasil kesimpulan; Pengaruh iklan, persepsi harga, citra merek, dan kepercayaan merek secara simultan, parsial dan dominan mempengaruhi keputusan pembelian.

Strategi yang berkaitan dengan iklan dan penetapan harga yang baik akan dapat memberikan pengaruh yang cukup signifikan terhadap keputusan pembelian konsumen dalam memilih suatu produk yang akan dibeli. Karena konsumen juga tidak dapat di pungkiri juga mempertimbangkan kedua faktor tersebut dalam pemilihan produk. Informasi yang jelas dengan iklan yang menarik, dan juga diikuti dengan harga yang cukup terjangkau namun dengan kualitas tetap terjaga akan sangat mudah mempengaruhi keputusan pembelian konsumen.

Untuk mengetahui tingkat ketepatan paling baik dalam analisa regresi digunakan Koefisien determinasi (R2). Koefisien determinasi (R2) nol variabel independen sama sekali tidak berpengaruh terhadap variabel dependen. Apabila koefisien determinasi semakin mendekati satu, maka dapat dikatakan bahwa variabel independen berpengaruh terhadap variabel dependen. 
Tabel 5: Hasil Uji R Squared

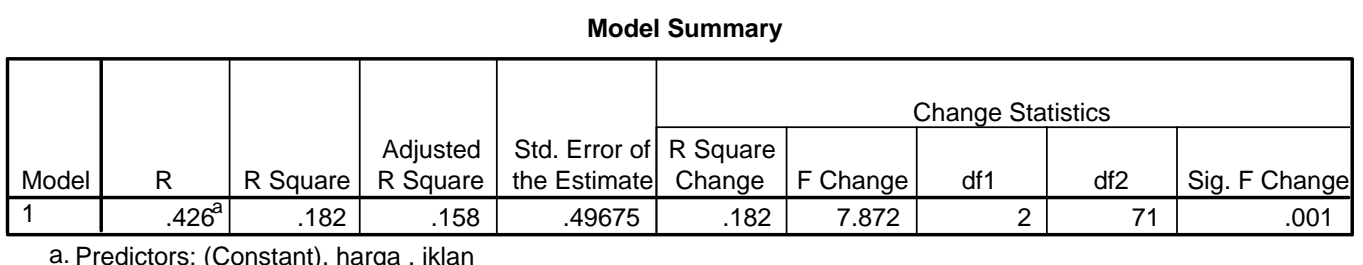

Sumber: Data Primer diolah, 2016

Dari hasil perhitungan diperoleh nilai R. Squared sebesar 0,182 atau 18,2\%. Hal ini berarti bahwa Iklan dan Harga terhadap mampu menjelaskan Keputusan Pembelian Minuman Teh Pucuk Harum yang diharapkan sebesar $18,2 \%$, sedangkan sisanya sebesar $81,8 \%$ dijelaskan oleh variabel yang lain di luar penelitian ini yang tidak terdapat dalam model penelitian ini.

\section{E. PENUTUP}

Dari hasil penelitian mengenai variabel-variabel iklan, harga berpengaruh secara nyata (signifikan) terhadap keputusan pembelian teh pucuk harum, dapat simpulkan bahwa variabel iklan dan harga berpengaruh secara simultan terhadap keputusan pembelian teh pucuk harum pada konsumen De Nala Food Court di Jombang. Karena itu disarankan kepada perusahaan agar dalam hal periklanan perusahaan harus mampu memberikan inovasi-inovasi dan penyajian iklan yang lebih unik dan menarik agar konsumen dapat lebih memahami dan tertarik dengan iklan yang disajikan oleh teh pucuk harum, sehingga dapat lebih memberikan pengaruh dalam pengambilan keputusan pembelian. Perusahaan dapat merangkul selebritis, artis dan model-model terkenal sebagai endoser iklan teh pucuk harum, agar konsumen akan mempunyai rasa bangga ketika mengkonsumsi produk. Selain itu, perusahaan diharapkan tidak hanya mampu memberikan harga yang terjangkau saja, tetapi harus memberikan kualitas yang baik dan mampu bersaing dengan harga produk-produk pesaing.

\section{DAFTAR PUSTAKA}

Alma, Buchari Dr. H. 2005. "Manajemen Pemasaran dan Pemasaran Jasa”. Bandung: CV Alfabeta.

Arikunto, Suharsimi. 2010. "Prosedur Penelitian : suatu Pendekatan Praktik”. Jakarta : Rineka Cipta.

Arshad, Hafiz Muhammad, Dr. Mudasar Noor, Wasim Ahmad, Sara Javed. 2013. "Impact of Effective Advertising on Consumer Buying Behavior : A Study of Mobile Phone Purchaser in Pakistan”. Journal of Basic and Applied Scientific Research

Augusty, Ferdinand. 2006. “Metode Penelitian Manajemen”. Semarang: Badan Penerbit Universitas Diponegoro.

David, Fred R. 2009. "Manajemen Strategis Konsep”. Edisi 12 Buku 1. Jakarta: Penerbit Salemba Empat.

Fred N, Kerlinger. 2006. ”Asas-asas Penelitan Behavioral”. Yogyakarta: Gajah Mada University Press. 
Ghozali, Imam. 2006. “Aplikasi Analisis Multivariate dengan Program SPSS. Cetakan Keempat. Semarang: Badan Penerbit Universitas Diponegoro.

Ginting, Nembah F. Hartimbul. 2011. “Manajemen Pemasaran”. Bandung: CV Yrama Widya.

Jefkins, Frank. 1997. “Periklanan”. Jakarta: Erlangga.

Kotler, Philip \& Gary Armstrong. 2001. "Prinsip-prinsip Pemasaran”, Jilid 1, Edisi Kedelapan. Jakarta: Penerbit Erlangga.

Kotler, Philip \& Gary Armstrong. 2001. "Prinsip-prinsip Pemasaran”, Jilid 2, Edisi Kedelapan. Jakarta: Penerbit Erlangga.

Kotler, Philip. 2003. “Manajemen Pemasaran”. Jakarta: PT. Indeks Kelompok Media.

Kotler, Philip. 2004. "Manajemen Pemasaran: Analisis, Perencanaan, Implementasi dan Kontrol, Edisi Sebelas”. Alih Bahasa, Hendra Teguh. Jakarta: Penerbit PT. Prenhallindo.

Kotler, Philip \& Kevin L. Keller. 2009. “Manajemen Pemasaran”. Edisi 13 Jilid 1. Penerbit Erlangga.

Kotler, Philip \& Kevin L. Keller. 2009. “Manajemen Pemasaran”. Edisi 13 Jilid 2. Penerbit Erlangga.

Kotler, Philip and Kevin Lane Keller. 2012. “Marketing Management 13”. New Jersey: Pearson Prentice Hall, Inc.

Pearce II, John A \& Richard B. Robinson Jr. 2013. "Manajemen Strategis: Formulasi, Implementasi, dan Pengendalian”. Edisi 12 Buku 1. Jakarta: Salemba Empat.

Pradana, Dimas Aditya. 2012. "Pengaruh Iklan, Persepsi Harga, Citra Merek, dan Kepercayaan Merek terhadap Keputusan Pembelian Smartphone Android Sony Xperia”. Jurusan Manajemen, Fakultas Ekonomi dan Bisnis, Universitas Brawijaya, J1. MT. Haryono 165, Malang.

Rosyid , Aji Normawan, Handoyo Djoko W, Widayanto. 2013. "Pengaruh Kualitas Produk, Citra Merek, Harga, dan Iklan Terhadap Keputusan Pembelian Sepeda Motor Honda Revo ( Studi Kasus pada Konsumen Sepeda Motor Honda Revo Astra Motor Kebumen)". DIPONEGORO JOURNAL OF SOCIAL AND POLITIC

Saladin, Djaslim. 2006. “Manajemen Pemasaran”. Edisi Keempat. Bandung: Linda Karya.

Shimp, Terence A. 2003. "Periklanan dan Promosi". Edisi V Jilid 1 dan 2. Jakarta: Penerbit Erlangga.

Sriyadi. 1991. "Bisnis Pengantar Ilmu Perusahaan Modern”. Semarang: IKIP Press Sudjana. 2001. "Metode Statistika” Edisi Revisi Cetakan Keenam. Bandung : Tarsito.

Sugiyono. 2014. "Metode Penelitian Bisnis”. Bandung: Alfabeta.

Swastha, Basu \& Irawan. 2005. "Manajemen Pemasaran Modern”. Yogyakarta: Liberty.

Swastha, Basu DH. 2010. "Manajemen Penjualan”. Yogyakarta: Penerbit BPFE.

Tjiptono, Fandy. 2008. "Strategi Pemasaran”. Yogyakarta: Penerbit Andi. 